\title{
Keragaan Padi Varietas Inpari 24 dan Varietas Mantap pada Budidaya Berbasis Organik
}

\author{
Swisci Margaret* dan Ade Ruskandar \\ Balai Besar Penelitian Tanaman Padi \\ Jl. Raya No. 9 Sukamandi, Subang, Jawa Barat 41256 \\ *Alamat korespondensi: swisci.margaret@gmail.com
}

\begin{abstract}
Performance of rice cv. Inpari 24 and Mantap in organic-based cultivation

Adaptable varieties are needed to support organic-based rice cultivation i.e varieties that can cope with the changes in environmental management without affecting its productivity and quality. The research aimed to obtain information about the effect of organic-based rice cultivation on the growth and yield of cv. Inpari 24 as functional rice and cv. Mantap as high yielding rice. The experiment was conducted in Sukamandi Experimental Station, Indonesian Center for Rice Research (ICRR) from June to September 2019. The experimental design used was nested design, rice cultivation (organic-based and existing) as main plot and varieties (Inpari 24 and Mantap) as subplot. Observations were made on the soil characteristics, plant growth, yield, and yield component. Six samples were taken for each cultivation and variety treatment. The effect of the treatment was analyzed using the t-test to find out the differences between treatments. The result showed that compared to existing cultivation, organicbased rice cultivation decreased the ability of cv. Inpari 24 and Mantap to get optimum growth and yield. For yield, the decline in functional rice cv. Inpari 24 reached $53.60 \%$, while the high yielding rice $\mathrm{cv}$. Mantap decreased yields of $23.43 \%$. The decrease was in line with the reduced ability to form tillers and panicle, reduced weight of 1000 grains, and the ability to maintain the greenness of the flag leaf until harvest. The smaller percentage of yields decreased on cv. Mantap showed that cv. Mantap was more adaptable to changes of organic-based cultivation management.
\end{abstract}

Keywords: Organic farming, Rice production, Sustainable farming

\begin{abstract}
ABSTRAK
Varietas yang dapat beradaptasi dengan perubahan pengelolaan lingkungan budidaya berbasis organik tanpa mempengaruhi produktivitas dan kualitasnya diperlukan untuk mendukung penanaman padi berbasis organik. Penelitian ini bertujuan untuk melihat pengaruh budidaya padi berbasis organik terhadap pertumbuhan dan hasil varietas Inpari 24 yang merupakan varietas beras fungsional dan varietas Mantap yang merupakan varietas potensi hasil tinggi. Percobaan dilakukan di Kebun Percobaan Sukamandi Balai Besar Penelitian Tanaman Padi (BB Padi) pada bulan Juni hingga September 2019. Percobaan menggunakan rancangan tersarang dimana budidaya padi (berbasis organik dan budidaya eksisting) sebagai petak utama dan varietas (Inpari 24 dan Mantap) sebagai anak petak. Pengamatan dilakukan terhadap karakteristik tanah, pertumbuhan tanaman, hasil dan komponen hasil. Pengambilan contoh dilakukan sebanyak enam ulangan untuk setiap perlakuan budidaya dan varietas. Pengaruh perlakuan dianalisis menggunakan uji t untuk mengetahui perbedaan antar perlakuan. Hasil kegiatan menunjukkan bahwa dibandingkan budidaya eksisting, budidaya padi berbasis organik menurunkan kemampuan varietas Inpari 24 dan Mantap untuk tumbuh dan memberikan hasil yang optimal. Penurunan hasil pada varietas padi fungsional Inpari 24 mencapai 53,60\%, sedangkan varietas potensi hasil tinggi Mantap mengalami penurunan hasil sebesar 23,43\%. Penurunan hasil ini selaras dengan penurunan kemampuan pembentukan anakan dan pembentukan malai, berkurangnya bobot gabah 1000 butir serta kemampuan mempertahankan kehijauan daun bendera hingga panen. Persentase penurunan hasil yang lebih kecil pada varietas Mantap menunjukkan bahwa varietas
\end{abstract}


tersebut lebih beradaptasi terhadap perubahan pengelolaan lingkungan yang terjadi pada budidaya organik.

Kata kunci: Pertanian organik, Produksi padi, Pertanian berkelanjutan

\section{PENDAHULUAN}

Pertanian berbasis organik merupakan salah satu implementasi perwujudan pertanian berkelanjutan. Hal ini dikarenakan pertanian organik memiliki efisiensi input-output yang lebih tinggi dan ramah lingkungan (Singh et al., 2005; Badgley et al., 2006; Chouichom \& Yamao, 2010). Penerapan teknik budidaya ini menjanjikan kepastian kelestarian lingkungan karena pupuk dan pestisida yang digunakan bersumber dari bahan organik dan pupuk kandang yang berasal dari limbah tumbuhan dan hewan (Prihtanti dkk., 2013; Priadi dkk., 2007), sedangkan pengendalian hama penyakit digunakan biopestisida dari ekstrak tumbuh-tumbuhan. Di Indonesia, usaha tani berbasis organik terus berkembang yang ditandai dengan meningkatnya luas lahan pertanian organik dari 69.605,9 ha pada tahun 2017 menjadi 251.630,98 ha pada tahun 2018 (AOI, 2019). Menurut David \& Ardiansyah (2017), perkembangan pertanian berbasis organik sejalan dengan kesadaran akan pentingnya pemenuhan kebutuhan bahan makanan sehat.

Teknik budidaya pertanian berbasis organik mengandalkan bahan-bahan alami tanpa input produksi berbahan kimia sintesis (Kennvidy, 2010). Ditambahkan Tarbiah dkk. (2010), pertanian berbasis organik juga memanfaatkan kearifan lokal yang ramah lingkungan dalam pengelolaan tanah, air dan tanaman. Berdasarkan hal tersebut, Winarno dkk. (2002) menyatakan bahwa Indonesia memiliki potensi besar untuk mengembangkan pertanian berbasis organik tidak terkecuali untuk budidaya padi. Indonesia memiliki banyak sumber daya lahan yang dapat digunakan untuk pengembangan sistem pertanian organik serta teknologi pendukung seperti teknik pengomposan, pengelolaan lahan tanpa olah tanah dan pembuatan pestisida hayati.

Beras organik merupakan produk organik kedua yang paling sering dibeli oleh konsumen (David \& Ardiansyah, 2017). Untuk memenuhi kebutuhan tersebut, konversi lahan organik padi terus mengalami peningkatan hingga 53.974,2 ha pada tahun 2018 (AOI, 2019). Selain pertambahan luas lahan, produktivitas lahan budidaya berbasis organik juga perlu diperhatikan. Hal ini dikarenakan perbedaan pengelolaan lingkungan pada budidaya padi berbasis organik dibandingkan budidaya eksisting dapat menyebabkan penurunan produktivitas padi budidaya berbasis organik sebesar 15-20\% (Surekha et al., 2013). Manajemen nutrisi menjadi salah satu tantangan dalam penerapan budidaya padi berbasis organik, karena $90 \%$ varietas padi yang ditanami saat ini merupakan varietas yang responsif terhadap pemberiaan nutrisi (Pirngadi, 2009). Pada budidaya organik, tingkat mineralisasi bahan organik lebih lambat dibanding pupuk anorganik. Hal ini menyebabkan ketersediaan nutrisi tidak sesuai dengan waktu dan jumlah kebutuhan tanaman (Berry et al., 2002; Sacco et al., 2015). Oleh karena itu, van Bueren et al. (2002) menyatakan bahwa diperlukan varietas yang spesifik untuk mendukung budidaya padi berbasis organik. van Bueren \& Osman (2002) menambahkan bahwa petani organik mengharapkan stabilitas hasil, sehingga diperlukan varietas yang dapat mengatasi perubahan pengelolaan lingkungan tanpa mempengaruhi produktivitas dan kualitas.

Sampai dengan saat ini Kementerian Pertanian telah merilis varietas-varietas padi dengan keunggulan seperti potensi hasil tinggi, tahan hama penyakit utama, dan pemenuhan kebutuhan pangan fungsional. Adanya budidaya padi berbasis organik, dapat memberikan nilai tambah dari keunggulan yang telah dimiliki varietas-varietas tersebut. Sebagai contoh, padi fungsional varietas Inpari 24 yang merupakan beras merah dengan kandungan antosianin 19,1 mg/1000 apabila diusahakan berbasis organik akan memantapkan keunggulannya sebagai bahan makanan sehat. Demikian pula varietas Mantap dengan potensi hasil tinggi dan rendemen beras kepala yang mencapai $\pm 96,31$, berpotensi untuk dikembangkan menjadi beras sehat dengan mutu premium apabila dibudidayakan berbasis organik. Untuk itu, diperlukan informasi kemampuan adaptasi dari varietas-varietas tersebut terhadap pengelolaan lingkungan budidaya berbasis organik. Tujuan kegiatan ini adalah melihat pengaruh budidaya padi berbasis organik terhadap pertumbuhan dan hasil varietas padi Inpari 24 dan varietas padi Mantap.

\section{BAHAN DAN METODOLOGI}

Kegiatan dilakukan pada bulan JuniSeptember 2019 di Kebun Percobaan Sukamandi Balai Besar Penelitian Tanaman Padi (BB Padi). 
Budidaya padi berbasis organik pada kegiatan ini merupakan musim tanam ke lima dari budidaya padi serupa pada lahan tersebut. Percobaan menggunakan rancangan tersarang dengan budidaya padi sebagai petak utama yang terdiri dari budidaya berbasis organik dan budidaya eksisting, sedangkan anak petak adalah varietas yang meliputi Inpari 24 dan Mantap. Inpari 24 merupakan salah satu varietas padi fungsional dengan warna beras merah yang memiliki potensi hasil 7,7 ton/ha, sedangkan Mantap merupakan varietas yang dirilis pada tahun 2019 dengan potensi hasil mencapai 9,1 ton/ha (Sasmita dkk., 2019). Budidaya padi berbasis organik dan budidaya eksisting dilaksanakan berdampingan dengan luasan petak utama adalah 1 ha, sehingga setiap varietas sebagai anak petak masing-masing di tanam pada luasan 0,5 ha. Pengambilan contoh dilakukan sebanyak enam ulangan untuk setiap perlakuan budidaya dan varietas.

Pada budidaya berbasis organik, sebelum dilakukan olah tanah lahan disemprot dengan dekomposer yang mengandung Trichoderma sp., Aspergilius sp., dan Trametes sp. untuk mempercepat pelapukan jerami. Persiapan lahan dilakukan dengan menerapkan olah tanah sempurna dan pemberian bahan organik sebanyak 2 ton/ha. Saat persemaian, benih diberikan seed treatment menggunakan pupuk hayati. Bibit dipindah tanam pada umur 18 hari setelah semai (HSS) dengan jumlah 2-3 bibit per lubang menggunakan jarak tanam Jajar Legowo 2:1 $(25 ; 12.5 ; 50) \mathrm{cm}$. Untuk pemenuhan kebutuhan unsur hara tanaman serta pengendalian hama dan penyakit, digunakan MOL (mikro organisme lokal) dari berbagai macam sumber bahan tanaman yang difermentasi. Pengendalian gulma dilakukan secara manual dengan tangan dan mekanik menggunakan gasrok. Tata kelola air dilakukan dengan irigasi berselang. Air irigasi yang masuk ke lahan budidaya berbasis organik terlebih dahulu melewati kolam yang ditanami eceng gondok dengan fungsi sebagai saringan.

Pada budidaya eksisting, persiapan lahan dilakukan dengan menerapkan olah tanah sempurna. Bibit dipindah tanam pada umur 18 hari setelah semai (HSS) dengan jumlah 2-3 bibit per lubang menggunakan jarak tanam Jajar Legowo 2:1 $(25 ; 12.5$; 50) $\mathrm{cm}$. Pemupukan diberikan sesuai dosis rekomendasi Peraturan Menteri Pertanian Nomor 40/Permentan/OT.140/4/2007 untuk Kec. Ciasem, Kab. Subang yaitu $300 \mathrm{~kg} / \mathrm{ha}$ Urea, $75 \mathrm{~kg} / \mathrm{ha}$ SP-36 dan $100 \mathrm{~kg} / \mathrm{ha} \mathrm{KCl}$. Pupuk diberikan dalam 3 tahap: (1) umur 7-10 hst (hari setelah tanam) dengan menggunakan $1 / 3$ pupuk $\mathrm{N}+$ pupuk $\mathrm{P}+1 / 2$ pupuk $\mathrm{K}$;
(2) umur 28 hst dengan memberikan $1 / 3$ pupuk N; dan (3) umur 40-45 hst dengan menggunakan $1 / 3$ pupuk $\mathrm{N}$ $+1 / 2$ pupuk K. Pengendalian hama dan penyakit selama pertumbuhan tanaman dilakukan sesuai dengan rekomendasi Pengendalian Hama Terpadu (PHT). Pengendalian gulma dilakukan manual dengan tangan dan secara kimia menggunakan herbisida dengan kandungan Triafamon $100 \mathrm{~g} / \mathrm{l}$ dan Tefuriltrion $200 \mathrm{~g} / \mathrm{l}$.

Pengamatan dilakukan terhadap karakteristik tanah lokasi kegiatan setelah percobaan, karakter pertumbuhan, komponen hasil dan hasil tanaman. Pengamatan tanaman dilakukan pada fase menjelang panen terhadap karakter tinggi tanaman; jumlah anakan per $\mathrm{m}^{2}$; kehijauan daun yang diukur menggunakan Konika Minolta chlorophyll meter SPAD-520; komponen hasil yang meliputi jumlah malai per per $\mathrm{m}^{2}$, jumlah gabah per malai, persen gabah isi dan berat gabah 1000 butir (kadar air 14\%); serta hasil gabah kering giling (ton/ha) yang diperoleh dari konversi hasil panen ubinan sebanyak tiga set legowo dengan panjang $3 \mathrm{~m}$ pada kadar air 14\%. Pengambilan contoh dilakukan sebanyak minimal enam kali untuk setiap perlakuan budidaya dan varietas. Pengaruh perlakuan dianalisis menggunakan uji t untuk mengetahui perbedaan antar perlakuan.

\section{HASIL DAN PEMBAHASAN}

\section{Karakteristik tanah lokasi kegiatan}

Analisis karakteristik tanah lokasi kegiatan setelah lima musim tanam dapat dilihat pada Tabel 1 . Lokasi kegiatan memiliki tanah yang didominasi oleh tekstur liat dengan $\mathrm{pH}$ pada kategori masam. Kandungan N-total tanah baik pada budidaya berbasis organik maupun eksisting termasuk dalam kategori rendah. Hal ini menunjukkan penambahan pupuk $\mathrm{N}$ dalam tanah tidak selalu diikuti peningkatan kandungan $\mathrm{N}$-total dalam tanah karena lebih banyak $\mathrm{N}$ yang hilang terangkut hasil panen atau melalui pelindian dan penguapan (Utami \& Handayani, 2003). Kandungan bahan organik yang mempunyai peran penting dalam memperbaiki sifat fisik, kimia, dan biologi tanah (Hartatik dkk., 2015) juga masih terlihat rendah baik pada budidaya berbasis organik maupun budidaya eksisting. Penambahan bahan organik ke dalam tanah selain memperbaiki produktivitas lahan, secara langsung dapat meningkatkan hasil tanaman padi (Pirngadi, 2009). Bi et al. (2009) menambahkan bahwa penambahan bahan organik dalam jangka panjang dapat meningkatkan hasil tanaman padi melalui 
peningkatan C-organik tanah serta perbaikan ketersediaan hara tanah.

Kandungan hara $\mathrm{P}$ dan $\mathrm{K}$ yang sangat tinggi juga terlihat tidak berbeda antara kedua teknik budidaya. Demikian pula dengan kapasitas tukar kation (KTK) tanah yang terlihat berada pada kategori rendah dengan kejenuhan basa sedang. Rendah nya KTK tanah menunjukkan pemberian bahan organik secara rutin selama 5 musim tanam pada budidaya padi berbasis organik belum cukup untuk perbaikan KTK tanah. Hal tersebut sesuai dengan Utami \& Handayani (2003) yang melaporkan pemberian bahan organik sampai dengan waktu 5 tahun terlihat belum cukup untuk meningkatkan KTK tanah. Namun demikian, kandungan asam humat yang merupakan hasil dari proses humifikasi bahan-bahan organik pada budidaya berbasis organik sudah terlihat lebih tinggi dibandingkan budidaya eksisting. Agustian dkk. (2004) menyatakan kandungan asam humat meningkat seiring lamanya pengomposan dan penambahan mikroorganisme perombak seperti pemberian dekomposer yang dilakukan pada percobaan ini. Adanya asam humat secara tidak langsung dapat mempercepat perbaikan status kesuburan tanah baik dalam sifat fisik, kimia, maupun biologi tanah. Perbaikan status kesuburan tanah diharapkan dapat meningkatkan serapan hara tanaman sehingga pertumbuhan dan produksi tanaman akan semakin optimal. Pada tanaman padi, asam humat dilaporkan dapat meningkatkan jumlah malai produktif, jumlah gabah per malai, pengisian gabah, bobot 1000 butir dan hasil gabah (Saha et al., 2013).

Tabel 1. Hasil analisis kimia tanah lokasi kegiatan, Kebun Percobaan Sukamandi, BB Padi, 2019.

\begin{tabular}{|c|c|c|c|c|c|}
\hline \multirow[b]{2}{*}{ No } & \multirow[b]{2}{*}{ Parameter } & \multicolumn{2}{|c|}{ Budidaya Berbasis Organik } & \multicolumn{2}{|c|}{ Budidaya Eksisting } \\
\hline & & $\begin{array}{c}\text { Nilai } \\
\text { Pengukuran }\end{array}$ & Kriteria & $\begin{array}{c}\text { Nilai } \\
\text { Pengukuran }\end{array}$ & Kriteria \\
\hline 1 & Tekstur & \multicolumn{2}{|c|}{ Lempung liat berdebu } & \multicolumn{2}{|c|}{ Liat Berdebu } \\
\hline 2 & $\begin{array}{l}\mathrm{pH} \mathrm{H}_{2} \mathrm{O} \\
\mathrm{KCl}\end{array}$ & $\begin{array}{l}5,1 \\
3,9\end{array}$ & Masam & $\begin{array}{l}5,2 \\
4,0\end{array}$ & Masam \\
\hline 3 & Bahan organik & & & & \\
\hline & C-organik (\%) & 1,43 & Rendah & 1,53 & Rendah \\
\hline 4 & N-total (\%) & 0,11 & Rendah & 0,13 & Rendah \\
\hline 5 & $\mathrm{P}_{2} \mathrm{O}_{5}(\mathrm{ppm})$ & 18,2 & Sangat Tinggi & 19,9 & Sangat Tinggi \\
\hline 6 & $\mathrm{~K}_{2} \mathrm{O}(\mathrm{ppm})$ & 82 & Sangat Tinggi & 119 & Sangat Tinggi \\
\hline 7 & $\mathrm{KTK}\left(\mathrm{NH}_{4} \mathrm{OAc} 1 \mathrm{~N} \mathrm{pH7}\right) \mathrm{cmol}(+) / \mathrm{kg}$ & 13,33 & Rendah & 15,48 & Rendah \\
\hline 8 & Kejenuhan Basa (\%) & 57 & Sedang & 58 & Sedang \\
\hline 9 & Asam Humat & 0,52 & & 0,38 & \\
\hline
\end{tabular}

\section{Pertumbuhan tanaman}

Pengamatan pertumbuhan tanaman dilakukan terhadap karakter tinggi tanaman, jumlah anakan per $\mathrm{m}^{2}$ dan kehijauan daun pada fase menjelang panen. Hasil pengamatan pada dua teknik budidaya padi yang berbeda, menunjukkan hasil bahwa kedua varietas yang digunakan memberikan respon yang serupa (Gambar 1), dimana hasil pengamatan pada budidaya eksisting menghasilkan nilai pengamatan yang nyata lebih tinggi dibandingkan budidaya berbasis organik berdasarkan uji t (Tabel 2). Selisih jumlah anakan per $\mathrm{m}^{2}$ antara budidaya berbasis organik dan budidaya eksisting pada varietas Inpari 24 mencapai 27,42\%, sedangkan varietas Mantap mencapai 18,33\%. Pembentukan jumlah anakan erat kaitannya dengan peluang pembentukan malai, sehingga penurunan jumlah anakan diduga dapat menurunkan pembentukan malai dan mempengaruhi hasil gabah (Shahidullah et al., 2009). Selain pembentukan malai, daun bendera yang tetap berwarna hijau hingga panen diduga lebih mendukung tanaman untuk berproduksi lebih baik karena penurunan fotosintesis yang lebih rendah (Luquez \& Guiamét, 2001; Rampino et al., 2006). Pada kegiatan ini penurunan nilai kehijauan daun bendera pada varietas padi fungsional Inpari 24 terlihat lebih besar dibandingkan varietas Mantap yang merupakan varietas potensi hasil tinggi. 
Tabel 2. Uji t terhadap 2 budidaya padi pada varietas Inpari 24 dan Mantap.

\begin{tabular}{|c|c|c|c|c|c|}
\hline \multirow{2}{*}{ Parameter } & \multicolumn{2}{|c|}{$t$ value } & \multirow{2}{*}{ Parameter } & \multicolumn{2}{|c|}{$t$ value } \\
\hline & Inpari 24 & Mantap & & Inpari 24 & Mantap \\
\hline Tinggi tanaman & $-8,37^{* *}$ & $-6,74^{* *}$ & Gabah per malai & $-7,34^{* *}$ & $0,15^{\mathrm{tn}}$ \\
\hline Anakan per $\mathrm{m}^{2}$ & $-4,18^{* *}$ & $-3,44^{*}$ & Persentase gabah isi & $2,61^{*}$ & $0,10^{\text {tn }}$ \\
\hline Kehijauan daun & $-10,85^{* *}$ & $-4,05^{* *}$ & Bobot 1000 butir & $-5,72^{* *}$ & $-3,00^{*}$ \\
\hline Malai per $\mathrm{m}^{2}$ & $-4,56^{* *}$ & $-2,94^{*}$ & Gabah kering giling & $-12,83^{* *}$ & $-4,67^{* *}$ \\
\hline
\end{tabular}

Keterangan: * berbeda nyata berdasarkan uji t pada taraf $5 \%,{ }^{* *}$ berbeda nyata berdasarkan uji t pada taraf $\%$, ${ }^{\text {tn }}$ tidak berbeda nyata menurut uji $\mathrm{t}$

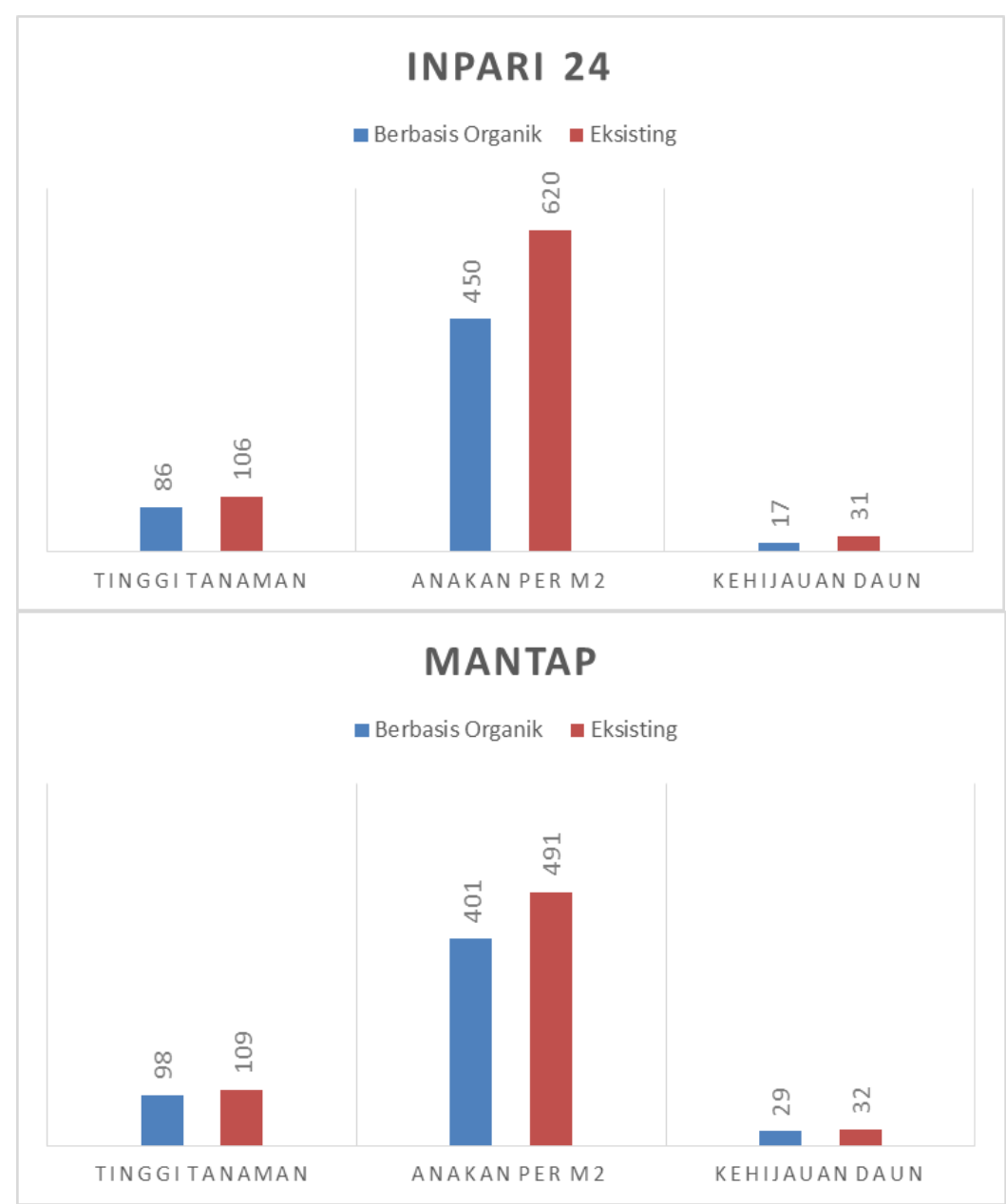

Gambar 1. Pertumbuhan varietas Inpari 24 dan varietas Mantap pada budidaya berbasis organik dan budidaya eksisting.

Hasil perbandingan pertumbuhan tanaman antara varietas Inpari 24 dan varietas Mantap, terlihat bahwa pada budidaya berbasis organik Inpari 24 lebih unggul dari segi jumlah anakan per $\mathrm{m}^{2}$. Namun pada postur tanaman dan kehijauan daun, varietas Mantap memiliki postur tanaman yang lebih tinggi dengan warna daun bendera yang lebih hijau saat panen. Unggulnya varietas Inpari 24 dari segi jumlah anakan per $\mathrm{m}^{2}$ dan varietas Mantap dari segi postur tanaman juga terjadi pada budidaya eksisting. Hal tersebut sesuai dengan deskripsi dari kedua varietas tersebut, dimana Inpari 24 merupakan varietas dengan anakan produktif \pm 16 batang dan tinggi tanaman $\pm 106 \mathrm{~cm}$, sedangkan varietas Mantap memiliki anakan produktif \pm 12 batang dengan tinggi tanaman $\pm 120 \mathrm{~cm}$ (Sasmita dkk., 2019). Untuk karakter warna daun bendera menjelang panen, dengan budidaya eksisting kedua varietas memiliki nilai kehijauan daun yang tidak berbeda nyata berdasarkan uji t (Tabel 3). Kemampuan varietas Mantap dalam mempertahankan kehijauan daun pada budidaya berbasis organik dapat memberikan kontribusi bagi 
varietas tersebut untuk mengoptimalkan potensi hasil. Menurut Fu et al. (2009) dan Kamal et al. (2019) peningkatan potensi hasil dari varietas dengan kemampuan mempertahankan kehijauan daun diperoleh melalui peningkatan pengisian gabah.

Tabel 3. Hasil uji t terhadap varietas padi pada budidaya padi berbasis organik dan budidaya eksisting.

\begin{tabular}{|c|c|c|c|c|c|}
\hline \multirow[b]{2}{*}{ Parameter } & \multicolumn{2}{|c|}{$t$ value } & \multirow[b]{2}{*}{ Parameter } & \multicolumn{2}{|c|}{$t$ value } \\
\hline & $\begin{array}{l}\text { Berbasis } \\
\text { Organik }\end{array}$ & Eksisting & & $\begin{array}{l}\text { Berbasis } \\
\text { Organik }\end{array}$ & Eksisting \\
\hline Tinggi tanaman & $-4,86^{* *}$ & $-2,26^{*}$ & Gabah per malai & $-3,43^{*}$ & $-7,51^{* *}$ \\
\hline Anakan per $\mathrm{m}^{2}$ & $3,37^{*}$ & $3,06^{*}$ & Persentase gabah isi & $3,72^{* *}$ & $-0,30^{\operatorname{tn}}$ \\
\hline Kehijauan daun & $-8,56^{* *}$ & $-1,29^{\text {tn }}$ & Bobot 1000 butir & $-2,60^{*}$ & $1,25^{\text {tn }}$ \\
\hline Malai per $\mathrm{m}^{2}$ & $2,51^{*}$ & $3,12^{*}$ & Gabah kering giling & $-4,85^{* *}$ & $2,92^{*}$ \\
\hline
\end{tabular}

Keterangan: ${ }^{*}$ berbeda nyata berdasarkan uji t pada taraf $5 \%,{ }^{* *}$ berbeda nyata berdasarkan uji t pada taraf $\%$, ${ }^{\text {tn }}$ tidak berbeda nyata menurut uji t.

\section{Hasil tanaman}

Seperti halnya pertumbuhan tanaman, gabah yang dihasilkan juga ditentukan oleh budidaya yang diterapkan. Hasil dari pertanaman ini menunjukkan bahwa hasil gabah tertinggi masih diperoleh dari budidaya eksisting, dimana Inpari 24 menghasilkan gabah kering giling (GKG) sebanyak 8,75 ton/ha dan varietas Mantap menghasilkan GKG sebanyak 7,64 ton/ha. Budidaya berbasis organik menyebabkan penurunan hasil hingga 53,60\% pada varietas padi fungsional Inpara 24 dengan hasil GKG 4,06 ton/ha, sedangkan pada varietas potensi hasil tinggi Mantap penurunan hasil hanya sebesar 23,43\% dengan hasil GKG 5,85 ton/ha (Gambar 2). Oleh karena itu pada budidaya berbasis organik, varietas Mantap menghasilkan GKG yang nyata lebih tinggi dibandingkan Inpari 24 berdasarkan uji t (Tabel 3). Besaran penurunan hasil GKG dari kedua varietas yang digunakan selaras dengan besarnya persentase penurunan pembentukan jumlah anakan per $\mathrm{m}^{2}$ serta kemampuan varietas mempertahankan kehijauan daun bendera hingga menjelang panen.

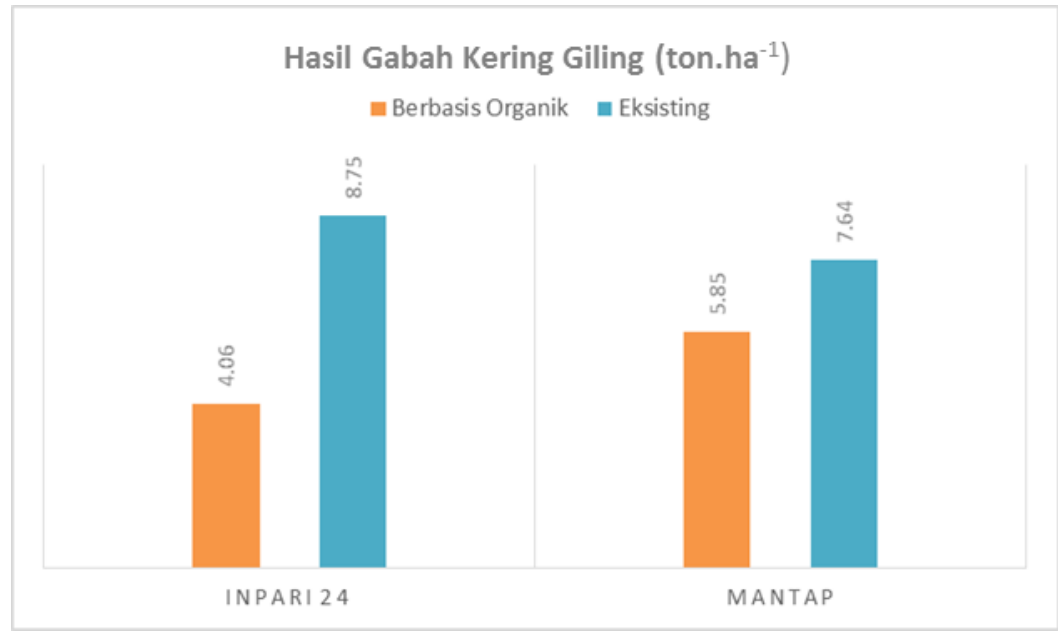

Gambar 2. Hasil gabah kering giling (GKG) varietas Inpari 24 dan varietas Mantap pada budidaya berbasis organik dan budidaya eksisting.

Pengamatan terhadap karakter komponen hasil yang meliputi jumlah malai per $\mathrm{m}^{2}$, gabah per malai, persentase gabah isi dan bobot 1000 butir menunjukkan hasil yang mendukung produksi gabah dari kedua varietas di dua teknik budidaya yang diterapkan. Budidaya padi berbasis organik berpengaruh terhadap penurunan hasil varietas Inpari 24 yang tampak dari menurunnya jumlah malai per $\mathrm{m}^{2}$, jumlah gabah per malai serta bobot 1000 butir. Namun disisi lain, budidaya berbasis organik dapat mendukung pengisian gabah varietas Inpari 24 meskipun peningkatannya terlihat belum 
berpengaruh terhadap hasil gabah. Berbeda hal nya dengan varietas Mantap, penurunan hasil pada budidaya berbasis organik diduga terjadi karena penurunan jumlah malai per $\mathrm{m}^{2}$ dan bobot 1000 butir dibandingkan budidaya eksisting. Meskipun terjadi penurunan hasil, pada budidaya berbasis organik varietas Mantap terlihat dapat mempertahankan jumlah gabah per malai serta persentase gabah isi (Gambar 3). Tidak terpenuhinya hara sesuai kebutuhan diduga menjadi penyebab rendahnya beberapa karakter komponen hasil pada budidaya berbasis organik. Kebutuhan hara pada budidaya berbasis organik dipenuhi dari pemberian pupuk organik yang mana tingkat mineralisasinya lebih lambat dibanding pupuk anorganik sehingga ketersediaan nutrisi dapat tidak sesuai dengan waktu dan jumlah kebutuhan tanaman (Berry et al., 2002; Sacco et al., 2015). Pada budidaya berbasis organik, varietas Mantap memiliki jumlah malai per $\mathrm{m}^{2}$ dan persentase gabah isi yang lebih rendah masing masing 10,05\% dan 5,49\% dibandingkan Inpari 24. Namun pada karakter jumlah gabah per malai dan bobot 1000 butir, varietas Mantap lebih unggul 67,90\% dan 3,01\% (Gambar 3 dan Tabel 3). Kontribusi karakter komponen hasil berupa banyaknya jumlah gabah per malai disertai bobot 1000 butir yang lebih tinggi pada varietas Mantap diduga menjadi penyebab hasil GKG varietas Mantap pada budidaya padi berbasis organik nyata lebih tinggi dari varietas Inpari 24. Banyaknya jumlah gabah per malai dari varietas Mantap dibandingkan Inpari 24 juga terjadi pada budidaya padi eksisting. Meskipun demikian, pada budidaya eksisting Inpari 24 merupakan varietas dengan hasil gabah tertinggi. Hal ini diduga dikarenakan Inpari 24 memiliki jumlah malai per $\mathrm{m}^{2}$ yang lebih banyak serta tidak berbeda nyata nya persentase gabah isi dan bobot 1000 butir dibandingkan varietas Mantap.

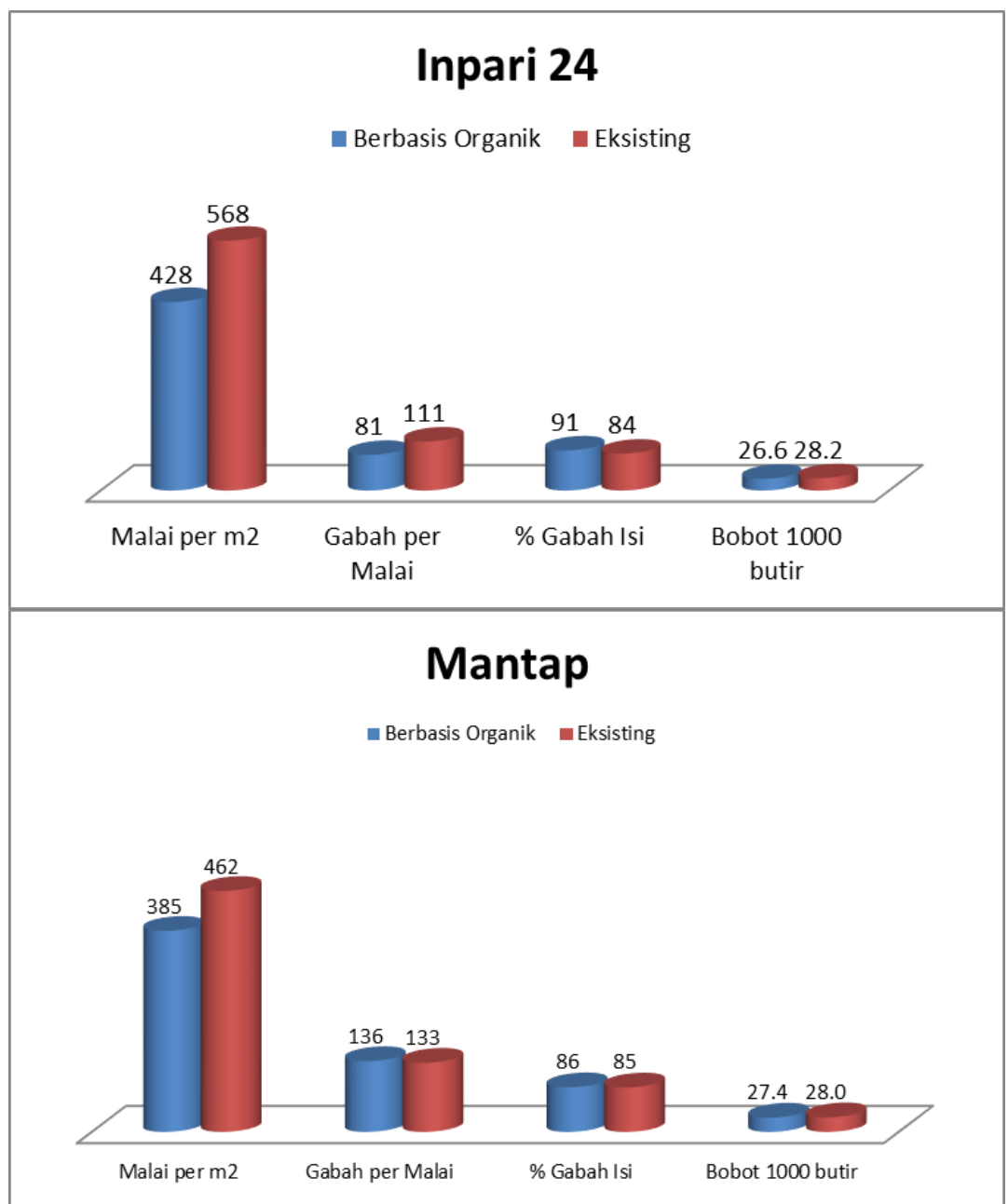

Gambar 3. Komponen hasil varietas Inpari 24 dan varietas Mantap pada budidaya berbasis organik dan budidaya eksisting 


\section{SIMPULAN}

Kandungan asam humat yang lebih tinggi pada budidaya padi berbasis organik diharapkan dapat mendukung perbaikan kesuburan tanah untuk optimalisasi produksi padi berbasis organik. Dibandingkan teknik budidaya eksisting, budidaya padi berbasis organik menurunkan kemampuan varietas padi Inpari 24 dan Mantap untuk tumbuh dan memberikan hasil yang optimal. Penurunan hasil pada varietas padi fungsional Inpari 24 mencapai $53,60 \%$, sedangkan varietas potensi hasil tinggi Mantap mengalami penurunan hasil sebesar 23,43\%. Penurunan hasil ini selaras dengan penurunan kemampuan pembentukan anakan dan pembentukan malai, berkurangnya bobot gabah 1000 butir serta kemampuan mempertahankan kehijauan daun bendera hingga panen. Persentase penurunan hasil yang lebih kecil pada varietas Mantap menunjukkan bahwa varietas tersebut lebih beradaptasi terhadap perubahan pengelolaan lingkungan yang terjadi pada budidaya organik.

\section{DAFTAR PUSTAKA}

Agustian, P Susila, dan Gusnidar. 2004. Pembentukan asam humat dan fulvat selama pembuatan kompos jerami padi. J. Solum 1(1):9-14.

AOI. 2019. Statistika Pertanian Organik Indonesia 2019. Aliansi Organis Indonesia 53 halaman.

Badgley, C, J Moghtader, E Quintero, E Zakem, M Jahi Chappell, K Avile's-Vazque'z, A Samulon, and I Perfecto. 2006. Organic agriculture and the global food supply. Renewable Agriculture Food System. 22:86108.

Berry, PM, R Sylvester-Bradley, L Philipps, DH Hatch, SP Cuttle, FW Rayns, and P Gosling. 2002. Is the productivity of organic farms restricted by the supply of available nitrogen. Soil Use Manage 18:248-255.

Bi, L, B Zhang, G Lium, Z Li, Y Liu, C Ye, X Yu, T Lai, J Zhang, J Yin, and Y Liang. 2009. Long-term effects o organic amendments on the rice yields for double rice cropping systems in subtropical China. Agriculture, Ecosystems and Environment 129:534-541.

Chouichom, S, and M Yamao. 2010. Comparing opinions and attitudes of organic and nonorganic farmers towards organic rice farming system in northeastern Thailand. Journal of Organics System. 5(1):25-35.

David, W, and Ardiyansyah. 2017. Perceptions of young consumers toward organic food in
Indonesia. Int. J. Agricultural Resources, Governance and Ecology 13(4):315-324.

Fu, JD, YF Yan, BW Lee. 2009. Physiological characteristics of a functional stay-green rice "SNU-SG1" during grain-filling period. Journal of Crop Science and Biotechnology. 12(1):47-52.

Hartatik, W, Husnain, dan LR Widowati. 2015. Peranan pupuk organik dalam peningkatan produktivitas tanah dan tanaman. Jurnal Sumberdaya Lahan. 9(2):107-120.

Kamal, NM, YSA Gorafi, M Abdelrahman, E Abdellatef, and H Tsujimoto. 2019. Staygreen trait: a prospective approach for yield potential, and drought and heat stress adaptation in globally important cereals. International Journal of Molecular Sciences. 20(23):5837

Kennvidy, SA. 2010. Organic rice farming systems in Cambodia: potential and constraints of smallholder systems in Takeo. International Journal of Environmental and Rural Development. 1(1): 62-67.

Luquez, VM, and JJ Guiamet. 2001. Effects of the 'stay green' genotype ggd1d1d2d2 on leaf gas exchange, dry matter accumulation and seed yield in soybean (Glycine max L. Merr.). Annals of Botany. 87: 313-318

Pirngadi, K. 2009. Peran bahan organik dalam peningkatan produksi padi berkelanjutan mendukung ketahanan pangan nasional. Pengembangan Inovasi Pertanian 2(1):48-64

Prihtanti, TM, S Hardyastuti, S Hartono, dan Irham. 2013. Multifungsi sistem usahatani padi organik dan anorganik. Jurnal AGRIFOR. 22(1): 11-21.

Priadi, D, T Kuswara, dan U Soetisna. 2007. Padi organik versus non organik: studi fisiologi benih padi (Oryza sativa L.) kultivar lokal Rojolele. Jurnal Ilmu-Ilmu Pertanian Indonesia. 9(2): 130-138.

Rampino, P, G Spano, S Pataleo, G Mita, JA Napier, N Di Fonzo, PR Shewry, and C Errotta. 2006. Molecular analysis of a durum wheat 'stay green' mutant: expression pattern of photosynthesis-related genes. Journal of Cereal Science. 43:160-168.

Sacco, D, B Moretti, S Monaco, and C Grignani. 2015. Six-year transition from conventional to organic farming: effects on crop production and soil quality. European Journal of Agronomy. 69:10-20. 
Saha, R, MAU Saieed, and MAK Chowdhury. 2013. Growth and yield (Oryza sativai) as influenced by humic acid and poultry manure. Universal Journal of Plant Science. 1(3):78-84.

Sasmita, P, Satoto, Rahmini, N Agustiani, DD Handoko, Suprihanto, A Guswara, dan Suharna. 2019. Deskripsi Varietas Unggul Baru Padi. Badan Penelitian dan Pengembangan Pertanian, Kementerian Pertanian 107 halaman.

Shahidullah, SM, M Musa, MA Hanafi, MR Ismail, and SM Abdus. 2009. Tillering dynamics in aromatic rice genotypes. International Journal of Agriculture and Biology. 11(5):509-514.

Singh, Y, B Singh, and J Timsina. 2005. Crop residue management for nutrient cycling and improving soil productivity in rice-based cropping systems in the tropics. Advances in Agronomy. 85:269-407.

Surekha, K, KV Rao, S Rani, PC Latha, and RM Kumar. 2013. Evaluation of organic and conventional rice production systems for their productivity, profitability, grain quality and soil health. Agrotechnology 11:1-6.

Tarbiah, S, S Raharja, dan B Purwanto. 2010. Kajian Tingkat Pendapatan Petani Sawah Irigasi dengan Diversifikasi Pola Tanam di Kabupaten Karawang, Jawa Barat. Jurnal Institut Pertanian Bogor 5(2): 101-110.

Utami, SNH, dan S Handayani. 2003. Sifat kimia entisol pada sistem pertanian organik. Ilmu Pertanian. 10(2): 63-69

van Bueren, ETL, and AM Osman. 2002. Organic breeding and seed production: the case of spring wheat in the Netherlands. Pp. 133161 in Organic Plant Breeding and Propagation: Concepts and Strategies. (ET lammerts van Bueren) $\mathrm{PhD}$ thesis Wageningen University, Wageningen, The Netherlands.

van Bueren, ETL, PC Struik, and E Jacobsen. 2002. Ecological concepts in organic farming and their consequences for an organic crop ideotype. Netherlands Journal of Agricultural Science 50: 1-26.

Winarno, FG, AK Seta, dan Surono. 2002. Pertanian \& Pangan Organik Sistem dan Sertifikasi. Bogor: MBRIO Press. 